Isabelle Buchstaller*

\title{
Community cityscape: modes of engagement and co-construction of the streetscape
}

https://doi.org/10.1515/lingvan-2020-0150

Received December 31, 2020; accepted January 7, 2021

\begin{abstract}
This contribution explores the bottom-up processes via which a community - or indeed special interest groups within a community - can influence the semiotic choices in the street-scape around them. I start by discussing the question to which extent the decision-making processes about street naming in different locales are transparent and open to public involvement. I also explore the instruments used by city councils and other administrative agencies to invite or indeed stifle public debate about street names, such as citizens surveys, op-eds in local newspapers and discussion fora as opposed to closed-off systems and exclusionary strategies. The paper moves on to consider grassroots movements opposing top-down decisions, including the mobilization of guerilla activity resulting in semi-spontaneous re-naming of street names and polls/lists of names and letters sent to the city council by concerned citizens. Finally, I consider politically motivated acts of vandalism resulting in semiotic erasure as well as resistance to official naming via inertia. The article closes with a brief discussion of the increasing commercialization of the linguistic streetscape, exploring the impact of market forces which claim authorship of the city text.
\end{abstract}

Keywords: commercialisation of the city-text; grassroots movement; linguistic landscape; semantic erasure; semiotic vandalism; top-down strategies vs. bottom-up strategies

\section{Introduction}

2020 has seen the toppling of statues, the defacing of monuments, mass protests and calls for the renaming of army barracks. The semiotic furor harnessed by the \#BlackLivesMatter movement has brought to the fore the potent symbolism of commemoration as it is inscribed in the public cityscape. But while the debate about who and what is commemorated in the official linguistic landscape is not new, the recent events have called attention to the clash of ideologies that lie behind commemorative naming. This paper focuses on the ways in which different stake-holders leverage power over the messages conveyed on street signs, and on the extent to which naming processes are open to consultation and democratic debate.

Landry and Bourhis' (1997) foundational paper classified toponymic (re)naming into bottom up vs. top down processes. Research has since found that pressures on street naming practices operate on several scales, involving municipal agencies, corporate interests and other, non-governmental stakeholders (Hagen 2011; Whelan 2011 inter alia). This complexity makes it difficult to disentangle the effect of top-down, legislative agencies (at city, regional or state level) versus grassroots agents or commercial forces. Critical toponymy has long highlighted the complex politics of street renaming (Berg and Vuolteenaho 2009; Rose-Redwood et al. 2018a:1), aiming to disentangle the links between governance "and the cultural landscape [by exploring]

This paper developed out of a residential workshop on street naming held at the Harnack Haus in Berlin in Summer 2018. I would like to thank the ISRF for funding this workshop, as well as the participants (Malgorzata Fabiszak, Seraphim Alvanides, David Wrisley, Rani Rubdy, Peter Tan, Maoz Azaryahu and Christoph Purschke) for the fruitful discussions and debates that have germinated this article. All remaining errors are obviously my own. I would also like to thank the joint German Research Foundation (DFG) - Polish Science Foundation (NCN) Beethoven Grant, which is supporting Malgorzata Fabiszak's and my ongoing research on the commemorative streetscape in East Germany and Poland.

*Corresponding author: Isabelle Buchstaller, Sociolinguistics Lab, University of Duisburg-Essen, Essen, Germany, E-mail: i.buchstaller@uni-due.de 
debates over naming .... as symbolic representations of much larger power struggles between competing interest groups" (Whelan 2011: 8). Linguistic landscape analysis has made some forays in this regard, pointing to the networks of authors, animators and principals involved in sign (co-)production, conception and placement (Buchstaller and Alvanides 2018; Kosatica 2020). To date, however, linguistic scholarship has yet to fully engage with critical geographical research into the complexities of "contested spatial practices" (RoseRedwood et al. 2010) and thus the question of "who has the power (or not) to name, who has a right to the city and to be visible within the streetscape, and whose visions of, and claims to, the urban past, present, and future will predominate" (Rose-Redwood et al. 2018a:1). More specifically, as Light and Young point out, what is currently "lacking is an understanding of how lower-level actors within and outside of urban administrations (committees, urban managers, block managers, work units, and workers) influence” the process of street naming (2018:198).

Critical toponomy research provides us with a useful approach to explore the ways in which different stake-holders aim to influence the public textuality, and on the extent to which the semiotic streetscape is open to consultation and democratic debate. Local authorities, regional governments and whole countries differ in (i) the transparency of the official street naming process, (ii) the influence allocated to different stakeholders by the legal frameworks in which street naming takes place and (iii) the amount and type of participation afforded to private citizens, special interest groups and commercial interests. I first address clear instances of top-down, governmental decision-making processes before engaging with ways in which special interest groups, individuals or market forces impact upon the city text, before exploring the ways in which more subversive voices intersect with official power structures in co-creating the city text.

\section{Exploring the role of stake holders in the streetscape}

\subsection{Governmental and non-governmental agencies}

Many polities have officially relegated street name authorship to governmental agencies or elected committees yielding top-down powers over the semiotic landscape. Allocating the performative power to name to a legitimated body interweaves "an authorized version of history into" the city text (Azaryahu 1996: 312). In some cases, transparent street naming mechanisms provide information about the processes and timelines involved as well as the contact details of the authorities responsible for the ratification and implementation of street sign semiotics, ideally in publicly accessible venues. The Northern Irish cities Derry, Belfast and Coleraine have put into effect such policies, "afford[ing] citizens the right to initiate proposals to make name changes and to propose an alternative language for those names" (Whelan 2011:10, see also Duminy 2018 for Durban, South Africa). A diametrically opposite approach to such explicitly participatory strategies is the "black box policy" epitomised by Luxembourg, where the absence of a front end renders the management of street signs impenetrable to the public (and to street name researchers, Purschke pers. comm.). Abu Dhabi is a similar case, where lack of information as to who makes decisions about street (re-)naming effectively precludes involvement in the denominational process (Wrisley pers. comm).

Successive shifts in nationally-sanctioned ideology in 20th century Europe illustrate the different scales at which official decisions over the semiotics encoded in the textual landscape are taken and ratified. In Germany, where Nazi top-down control over public semiotics ended after WWII (Buchstaller et al. to appear), toponymic jurisprudence moved above the national level to the Control Council and Coordinating Committee of the Allied Control Authority. ${ }^{1}$ After the swift cleansing of major Nazi party members and well-known war criminals, the process of "symbolic retribution" (Azaryahu 2011:29) gradually lost steam. To date, residue third Reich heritage in urban toponymy is an ongoing issue, with hundreds of street names commemorating "personnages or events that represent viewpoints or ideologies which are not acceptable" (Drammeh 2019).

1 https://www.loc.gov/rr/frd/MilitaryLaw/Enactments/Volume-III.pdf, accessed 1. November 2020. 
Local debates weighing the semantic impact of street names versus arguments of practicality (see Buchstaller et al. to appear) tend to result in sporadic, and often highly contested acts of decommemoration and renaming. The city of Münster (Presseamt Stadt Münster 2011) illustrates how governmental decision making can build on democratic consultative processes. In April 2010, and on the basis of the joint decision of the council of the city elders and the city mayors, the city formed a "committee 'street names' ... consisting of representatives of all parliamentary groups, the lord mayor ... chairing the committee, ... [with two historians as] scientific consultants". 2 This committee's unanimous recommendation to change eight street names (and add explanatory plaques to the remaining four) was debated in a town hall meeting. In consultation with the city representatives, the local councils finally decided in favour of the changes.

In former East Germany, where street (re)naming faces another layer of residue semiotics, local authorities have found bespoke solutions to deal with socialist heritage in the city text. The small town AnnabergBuchholz held an "ideas competition for new streets in the urban area" ${ }^{3}$ in the local newspaper in 1994, which produced more than 200 candidate names. The city of Leipzig created an internal task force of the city council to examine all (re)namings after 1945. This committee includes representatives of the department of taxes and election, the department for planning, design, construction and maintenance of fixed structures and ground facilities, the department of water, the department for city planning and the city archive. Political parties have nominated informed citizens and informal participation is also possible. The task force, which reports to the city council, meets once or twice a year, occasionally consulting historians and archivists to discuss suggestions for renaming, which any citizen can make. This process has resulted in a wish list, with special interest groups vetting for certain personages to be commemorated ${ }^{4}$ and the board ensuring that opportunities for textual allocation are distributed on the basis of parity. Thus, while the smaller local authority AnnabergBuchholtz embraces a fundamentally base-democratic solution, Leipzig relies on a more complex consultative process to provide different stakeholders with the opportunity to co-author their city text. Both are demonstratively participatory, which might be expected given the political sensitivity of the semiotic legacy, and few decisions are heavily contested.

Other consultative decisions have been more factitious, resulting in expressions of popular discontent. Many US cities councils, for example, are actively soliciting the opinion of local residents when faced with the commemorative heritage honouring Ku Klux Klan and Confederate leaders. In Atlanta (Georgia), the "alt-right rally in Charlottesville moved the local leadership to ... create ... the Confederate Monuments Advisory Committee in August 2017. [This committee] ... identified six monuments and roughly 30 street names as candidates for renaming", a decision that is heavily contested (Mock 2018). In Durban, South Africa, a consultative process via advertisements in the local newspaper resulted in mass protests, which I will discuss below (Duminy 2018).

Given the contested nature of commemorative city texts, some governmental agencies have manufactured apparent citizen consultation or claim to react to public pressure in order to camouflage deeply undemocratic, top-down resolutions. The city council of the Kazakh city Almaty, for example, renamed one of its most prestigious thoroughfares after former president Nazarbayev. While the city mayor claimed "his office had been swamped by petitions urging the move from representatives of the intelligentsia, nongovernmental groups and regular members of the public" (Kumenov 2017), no such evidence was produced and online reactions suggested otherwise (see also Azaryahu 2018 for apparent public demand for street renaming in East Berlin in 1951).

Overall, thus, the analysis of superficially top-down or bottom-up strategies requires us to differentiate between "the 'input' ... [hence] the names offered for commemoration, and the 'output', [namely] the actual names approved as worthy of official commemoration" as well as the various scales of operation and the stakeholders involved in the decision-making process (Azaryahu 2011:30). The following sections will consider the political limits of top-level political authorities to implement or indeed enforce changes in street names (Rose-

2 https://www.muenster.de/stadt/strassennamen/pdf/strassennamen2011-06.pdf, accessed 1. November 2020.

3 Ideenwettbewerb zu neuen Straßen im Stadtgebiet, Stadtanzeiger Annaberg-Buchholz 02.06.1994, accessed 1. November 2020.

4 For example, the Christian democratic party (CDU), has long been lobbying for former chancellor Helmut Kohl to be commemorated. 
Redwood et al. 2018b: 312). I will illustrate different forms of resistance and attempts at counter-memory formation (Alderman 2015).

\subsection{Public protests and demonstrations}

The violent protests that accompanied the decommemoration and removal of statues of confederate generals in the USA have - to my knowledge - not (yet) been reported for street name changes. However, a number of politically motivated renamings have been met with public unrest. Adebanwi (2018:227) reports that the toponymic cleaning of colonialist legacy from the Durban streetscape resulted in "a 6,000-strong group of protesters march[ing] through the city's downtown". Marchers complained that some names were chosen "not to honor modern South African heroes, but to heap glory on the African National Congress." In Sarajevo, citizens took to the street when a commission "suggested renaming Sarajevo's main artery, ulica Maršala Tita (after the Yugoslav statesman Josip Broz Tito)... [since] they did not want to erase the memory of their former president” (Palmberger 2018:179).

Notably, as Rose-Redwood et al. (2018b:312) illustrate, public demonstrations have turned spatial practices into symbols of social empowerment and memory building. In Prairie View (Texas), massive protests after the death of an African American woman in police custody resulted in the City Council voting to dedicate the road where she had been stopped and assaulted by police as a memorial. By connecting with "the wider \#SayHerName campaign, which highlights ... experiences of black female victims of police brutality”, the movement was able to link the victim's name with processes of resistance to subjugation and spatial justice.

\subsection{Petitions, complaints and suggestions}

Apart from mass protests, individuals, special interest groups and neighbourhood associations use a number of strategies to voice their opinions about the city text and to suggest alternative candidates to the ones officially commemorated and/or proposed.

The power of petitions is revealed by an example from 1945, when the residents of the Leo-SchlageterStreet in Leipzig collected signatures arguing that Schlageter was a Nazi, proposing instead an "inhabitant of our street ... Georg Schwarz ... [the] bravest in [the] battle against Hitler [who] ... died at the guillotine on 12. January 1944". The street was thus named in August 1945, but not before another resentful letter by the street's inhabitants 10 days after the council proposed a different name - Gundorfer Straße - in May 1945.

Similarly, in Bucharest, a group of residents formally submitted a request to the ruling party controlling City Hall for "Ion Mihalache Boulevard" to return to its original name "May 1 Boulevard" (Light and Young 2018:196).

Individual "concerned citizens" putting pressure on the municipal council by writing letters, urging them to implement what they consider to be necessary changes in street names can be a successful strategy, as was the case when Haifa became predominantly Jewish as part of the 1947 partition plan of British Mandate Palestine (Azaryahu 2018:62). In post-apartheid South Africa, the replacement of road names commemorating the country's colonial and apartheid past resulted in 12,000 written public objections to the Durban renaming project (Duminy 2018:248). At the same time, newspapers "bulged with indignant letters "questioning the legitimacy of the process (Wines 2007). Rubdy (this volume) similarly illustrates that the commemoration of Hindu heritage and the decommemoration of Muslim rulers during the Saffron revolution in India triggered significant backlash, including furious letters to the editor. Adebanwi (2018) reports on yet another instrument against street name changes, detailing a number of court cases aiming to halt post-apartheid street renaming in Pretoria and Durban.

In the German city of Freiburg, repeated complaints about certain street names led the city council to form a committee of experts (political scientists, historians, and gender studies scholars) tasked with investigating whether the names of 1,300 streets "are still appropriate based on modern scientific knowledge". The 
consensus is that public involvement in street naming decisions is "not necessarily easy to deal with but tends to be productive in nature". ${ }^{5}$ As these cases show, citizen-led grassroots movements can result in local governments' changing or at least considering the removal of certain commemorative semantics.

\subsection{Inertia and subversive strategies}

The official act of street (re)naming depends upon its performative uptake in everyday urban life. On the most mundane level, thus, inertia can undermine official top-down renaming strategies when citizens continue to enact older, competing city texts (Rose-Redwood et al. 2018a:5). Some (post)colonial settings reveal that official naming systems were never implemented by the citizens themselves: The inhabitants of many municipalities in Sub-Saharan Africa (Bigon and Njoh 2018), for example, continue to have their own, local system of toponymic inscription which they use independently of the superimposed colonial odonymy. In Singapore, an official, British-Colonial and a vernacular, Asian-local (mainly Cantonese) nomenclature of street naming result in competing, exclusionary ontologies (see Azaryahu 2011: 31; Yeoh 1992).

Even when governments adopt top-down, "official” blanket renaming policies, "there is no certainty that such a policy will be uniformly applied throughout the country" (Light and Young 2018: 188). As the slow and incomplete decommemoration of communist semantics in many European countries reveals, toponymic change is often incomplete, resulting in residual semantic and odonymic inertia (see Azaryahu 2018 for East Berlin). In post-socialist Bucharest, managers of housing blocks were slow or did not change the small metal plates indicating the official street name, which Light and Young (2018:193) relate to habit rather than conscious resistance. At the same time, many Bucharesters (Light and Young [2018]), inhabitants of Mostar (Palmberger 2018) or St. Petersburg (Marin 2018) either refuse to use unpopular new "official” toponomy or simply continue with entrenched, familiar names.

Apart from such cases of odonymic inertia, special interest groups can resort to subversive forms of social activism to effectuate a diverse set of goals, such as, for example, the (sometimes short term) recognition of minority groups. The under-representation of minority groups in urban semiotics, coupled with the impression that its status quo is maintained by hegemonic power structures, has resulted in compensatory naming by a number of guerilla movements. In 2018, feminist action groups superimposed women's names on street signs in Paris and in several Dutch cities (Jaffe 2015; Pieters 2018). In 2016 in Toronto, the Ogimaa Mikana Project applied stickers with the Anishinaabe place names above the official names of street signs (CBC News 2016). In 2018, in the course of a high profile court-case against the accomplices of a Neonazi terror cell, a group of leftwing activists commemorated the victims by renaming 200 streets across Germany (Berliner Zeitung 2018). Finally, protests against Germany's colonial past have been riveting Berlin's "African quarter" for years, with activists symbolically renaming Moor-street into "Anton- Wilhelm-Arno-street [after] ... the first black student and university scholar in Germany” (Taz 2017).

As guerrilla movements in Israel and the United States reveal, subversive strategies can be reactionary or punitive in nature. In 2019 several main streets in Tel Aviv were changed to the names of famous Hamas personnel and to places where terror attacks perpetrated by Palestinian guerillas had taken place. The renaming was done by the "Israel Victory Project" in protest against what they saw as a "weak" Israeli response to Palestinian terrorism (Blumenthal 2019). The hope for politics of representation to influence political strategy is not without basis. As the case of Khashoggi Way in Washington DC reveals, insurrectionary movements can sediment into more permanent textualities. In 2018, a crowd-sourced organisation installed the sign Khashoggi Way outside of the Saudi Arabian Embassy on New Hampshire Avenue in Washington. While the sign was taken down after 20 hours, "the Advisory Neighborhood Commission that covers the Foggy Bottom area, ... [and which has the juridical rights to effectuate street name changes] voted [at the end of November 2018] to approve changing that stretch of New Hampshire Avenue to Khashoggi Way" (Robinson 2018, italics mine). The official renaming process is delayed by the laws of Washington state's requirement for

5 https://kommunal.de/strassenumbenennung-strassennamen, accessed 15. November 2020. 
commemorated persons to have been deceased for at least two years before a street can be named in their honour.

\subsection{Acts of destruction and vandalism}

Street signs are frequent targets of antisocial behaviour, being defaced with paint (Duminy 2018; Sweeney 2019), ripped off, bent out of shape (Berry 2018) or ravaged by bullets. Light and Young (2018) provide an example from Moscov, where the street renaming of Big Communist Street to Alexander Solzhenitsyn Street, in 2008 stirred up sentiments. While "Muscovites signed a petition by the hundreds, .... residents of the street took more direct action, physically tearing street signs from buildings" (2018:196-197). In Brazil, the destruction of street signs formed part of a political publicity stunt by the right-wing party PSL. The Rio de Janeiro PSL candidate posted a photo on Facebook in which he could be seen destroying a street name sign that honoured a socialist/left wing politician who was brutally murdered less than a year prior (Heiber 2018). In India, street sign vandalism forms part of the Hindu nationalist Bhartiya Janata Party's aim to eradicate the Muslim heritage from India's collective memory as part of the Saffronisation of India. "In May 2015, many street signs in New Delhi carrying Urdu/Muslim names, including Aurangzeb Road, named after the sixth Mughal emperor, were painted black by Shiv Sena Hindustan, a radical Hindu organisation. Later ... that year, the ruling BJP officially changed the name ... to APJ Abdul Kalam, a pro-BJP ex-president of India” (Ahmad 2018). As can be seen by these examples, the condoning and indeed explicit sanctioning of toponymic vandalism suggests that violent acts of textual cleansing can form part of a take-over strategy by a new political power.

A much more subversive form of vandalism, finally, is failure to upkeep unwanted toponymic infrastructure. As Bigon and Njoh (2018:212) report for Douala, due to sheer neglect, the street signs issued by the German colonial forces are faded and barely visible with "the post [being] twisted and either lying on, or barely sustained at an irregular angle to, the ground".

\subsection{Commercial interests}

While the corporate sponsorship of schools, stadiums or metro stations has been amply documented, its infringement into street name authorship is less conspicuous. Some forms of commercialisation are short-lived publicity stunts, such as the renaming of New York City's “West 53rd Street [into] U2 Way .... for ... one week, .... to ... generat[e] publicity for ... their new album and forthcoming world tour” (Whelan 2011: 11). Under-theradar commercial takeovers of street naming include businesses buying the naming rights of the street in which they are situated. In Coburg (Bavaria), a car parts supplier successfully lobbied to name a street after its founder (Max Brose). Leipzig has an Amazon-street (named in 2006 after the logistics center located there). Note that attempts at commercial takeover are not always successful, as illustrated by Annaberg-Buchholz, where the city council decided against the proposed Metzner-Brothers-street (after a container-producing plant) and for the more general Industry-street to avoid setting a precedent.

Madden (2018) draws our attention to "real estate developers and residents of expensive private housing us[ing] toponymy to legitimise their privileged positions", designating exclusive-sounding names to increase property value in their neighbourhoods. Rose-Redwood (2018) provides a historical illustration of this "reputational politics" (Alderman 2002) strategy as residents of Fifth Avenue in NYC generated symbolic prestige and cultural recognition while marginalising and excluding other populations. Also the seemingly innocuous and banal street naming for heritage purposes needs to be seen through the lens of corporate interests (Berg 2011; Modan 2018). In the former mining town of Annaberg-Buchholz, for example, the (re)naming of streets after mining-related concepts (cobalt street, zinc street, mine street etc.) as part of a consolidated heritage tourism policy taps into the town's touristic and thus commercial potential (see also Coupland and Garrett 2010). 
Relatedly, "despite a general post-apartheid movement favoring African place names (as opposed to British or Afrikaner toponyms) ... [there have been arguments] that [such] changes would hinder efforts to promote the country internationally as a destination for tourists or businesses" (Guyot and Seethal 2007: 60, see Hagen 2011: 25-26). Note in this respect that commercial interests took note of the stickers with indigenous translations of Toronto street names discussed above, which were quickly incorporated into a tourist initiative of the Business Improvement Area (Rose-Redwood et al. 2018b).

The streetscape of the Gulf states features two processes via which material culture is currently becoming commodified in public odonymy. Since the dearth of publicly-sanctioned street signs necessitates the reliance on other aspects of city architecture, informal commercial signposts (such as business advertisements and shop names) have become ratified as toponymic markers, starting to play a role in what Bourdieu (1985:732) called the "official nomination" of the permanent toponymic streetscape (Wrisley pers. comm.). Given this dynamic streetscape, the Government of Dubai has recently announced the development of an online geoaddressing application in partnership with Garmin. The Emirati government-issued digital interface allows smartphone or OS-users access enhanced, digitally mediated spaces whereas users of "“dumb' mobile technology, or unconnected users without Internet, computers, or a mobile device ... are relegated to using an analog version of the city ... [which] further stratifies a city already divided by wealth, class, and status" (Sotoudehnia 2018:298). Cases such as these force us to rethink street names not merely as spatialorientational or political-cultural in nature but "also as an integral strategy of entrenching neoliberal corporatism within ... public space” (Rose-Redwood 2011: 8).

\title{
3 Conclusion
}

This paper explores "the competing political agendas embedded in place-name debates ... how [different stakeholders and interest] groups ... influence the outcome of these debates" (Hagen 2011: 25-26). As Verdery (1991: 84) rightly pointed out, "policies may be made at the center, but they are implemented in local settings, where those entrusted with them may ignore, corrupt, overexecute, or otherwise adulterate them." As this paper illustrates, non-official, non-governmental groups or even individuals are exploiting different grassroots, jurisdictional or subversive strategies to claim authorship in the urban streetscape. Some rely on and support acts of public vandalism to enshrine their version of society into the textual landscape. This "demonstrates ... [the] limits to the sovereign assertion of a monopoly over naming practices, since, whether through unconscious habit or overt resistance, the users of urban space may undercut the legitimacy of officially sanctioned street names" (Rose-Redwood et al. 2018a: 16). Top-down decision making bodies have assumed different strategies on how to deal with subalterns' demands for co-authorship, some using exclusionary strategies, and others assuming consultative processes to forge consent on the textual landscape. Hence, what might initially look like a top-down governmental decision making process is often designed to be participatory. Finally, as Rose-Redwood (2011:34) observed "one of the major transformations that will likely reshape the toponymic landscape of the next century is the commercialization of public place-naming systems".

\section{References}

\author{
Adebanwi, Wale. 2018. In Reuben Rose-Redwood. In Derek Alderman \& Maoz Azaryahu (eds.), The Political life of urban \\ streetscapes: Naming, politics, and place, 218-239. London: Routledge. \\ Ahmad, Rizwan. 2018. Renaming India: Saffronisation of public spaces. https://www.aljazeera.com/indepth/opinion/renaming- \\ india-saffronisation-public- spaces-181012113039066.html (accessed 10 January 2020). \\ Alderman, Derek. 2002. Street names as Memorial Arenas: The reputational politics of commemorating Martin Luther King Jr. in a \\ Georgia County. Historical Geography 30. 99-120.
}


Alderman, Derek. 2015. Naming streets, doing justice? Politics of remembering, forgetting, and finding surrogates for African American Slave Heritage. In S. Choo (ed.), Geographical names as cultural heritage, 193-228. Seoul: Kyung Hee University Press.

Azaryahu, Maoz. 1996. The power of commemorative street names. Environment and Planning D: Society and Space 14(3). 311-330. Azaryahu, Maoz. 2011. The critical turn and beyond: The case of commemorative street naming. Acme 10(1). 28-33.

Azaryahu, Maoz. 2018. Revisiting East Berlin and Haifa: a comparative perspective on renaming the past. In Rose-Redwood Reuben, Alderman Derek \& Maoz Azaryahu (eds.), The political life of urban streetscapes: Naming, politics, and place, 56-73. London: Routledge.

Berg, Lawrence. 2011. Banal naming, neoliberalism, and landscapes of dispossession. Acme 10(1). 13-22.

Berg, Lawrence \& Jani Vuolteenaho (eds.). 2009. Critical toponymies: The contested politics of place naming. Farnham: Ashgate. Berliner Zeitung. 2018. In ganz Deutschland Linke Aktivisten benennen Straßennamen nach NSU- Opfern. https://archiv.berlinerzeitung.de/politik/in-ganz-deutschland-linke-aktivisten-benennen-strassennamen-nach-nsu-opfern-30937358 (accessed 19 January 2020).

Berry, Frankie. 2018. Thugs on vandalism rampage target street signs in Harpenden. https://www.hertsad.co.uk/news/thugsvandalise- 20-street-signs-in-harpenden-1-5386035 (accessed 19 January 2020).

Bigon, Liora \& Ambe Njoh. 2018. Toponymic complexities in Sub-Saharan African cities: informative and symbolic aspects from past to present. In Reuben Rose-Redwood, Derek Aldermann \& Maoz Azaryahu (eds.), The political life of urban streetscapes: Naming, politics, and place, 202-217. London: Routledge.

Blumenthal, Itai. 2019. Israelis get lost on Yasser Arafat. https://www.ynetnews.com/articles/0,7340,L-5565074,00.html (accessed 19 January 2020).

Bourdieu, Pierre. 1985. The social space and the genesis of groups. Theory and Society 14. 723-744.

Buchstaller, Isabelle \& Seraphim Alvanides. 2018. Linguistic landscapes and the ideology of language choice: The case of the Marshall Islands. Journal of Linguistic Geography 5(2). 67-85.

Buchstaller, Isabelle, Seraphim Alvanides, Frauke Griese \& Carolin Schneider. To appear. Competing ideologies, competing semiotics: A critical perspective on politically-driven renaming practices in Annaberg-Buchholz, Eastern Germany. In Evelyn Zigeler \& Heiko Marten (eds.), Linguistic landscapes im Deutschsprachigen Kontext. Frankfurt: Lang.

CBC News. 2016. New street signs put Toronto's Indigenous history front and centre. https://www.cbc.ca/news/canada/toronto/ new-street-signs-put-toronto-s-indigenous- history-front-and-centre-1.3771548 (accessed 27 April 2020).

Coupland, Nikolas \& Peter Garrett. 2010. Linguistic landscapes, discursive frames and metacultural performance: The case of Welsh Patagonia. International Journal of the Sociology of Language 205. 7-36.

Drammeh, Njema. 2019. Steit um Strassennamen. Kommunal. https://kommunal.de/strassenumbenennung-strassennamen (accessed 19 January 2020).

Duminy, James. 2018. Street renaming, symbolic capital, and resistance in Durban, South Africa. In Reuben Rose-Redwood, Derek Alderman \& Maoz Azaryahu (eds.), The political life of urban streetscapes: Naming, politics, and place, 240-258. London: Routledge.

Guyot, Sylvain \& Cecil Seethal. 2007. Identity of place, places of identities: Change of place names in post-apartheid South Africa. South African Geographical Journal 89. 55-63.

Heiber, Rafael. 2018. Brazilian democracy’s paroxysm. https://www.opendemocracy.net/en/democraciaabierta/brazilandemocracys-paroxism/ (accessed 19 January 2020).

Hagen, Joshua. 2011. Theorizing scale in critical place-name studies. Acme 10(1). 23-27.

Jaffe, Eric. 2015. The streets of Paris, renamed after women. https://www.citylab.com/design/2015/08/the-streets-of-parisrenamed-for- women/402526/ (accessed 19 January 2020).

Kosatica, Maida. 2020. To appear. The burden of traumascapes: Discourses of remembering in post-war Bosnia- Herzegovina and beyond. London: Bloomsbury Publishing.

Kumenov, Almaz. 2017. Kazakhstan: Street named after president (predictably). https://eurasianet.org/kazakhstan-street-namedafter-president- predictably (accessed 19 January 2020).

Landry, Richard \& Richard Bourhis. 1997. Linguistic landscape and ethnolinguistic vitality: An empirical study. Journal of Language and Social Psychology 16(1). 23-49.

Light, Duncan \& Craig Young. 2018. The politics of toponymic continuity: the limits of change and the ongoing lives of street names. In Reuben Rose-Redwood, Derek Aldermann \& Maoz Azaryahu (eds.), The political life of urban streetscapes: Naming, politics, and place, 185-201. London: Routledge.

Madden, David. 2018. Pushed off the map: Toponymy and the politics of place in New York City. Urban Studies 55(8). $1599-1614$.

Marin, Anais. 2018. Toponymic changes as temporal boundary-making: street renaming in Leningrad/St. Petersburg. In Reuben Rose-Redwood, Derek Alderman \& Maoz Azaryahu (eds.), The political life of urban streetscapes: Naming, politics, and place, 132-149. London: Routledge.

Mock, Brentin. 2018. Say goodbye to Confederate Avenue. https://www.citylab.com/equity/2018/09/costs-renamingconfederate-street-names- atlanta/571279/ (accessed 19 January 2020).

Modan, Gabriella. 2018. The semiotics of urbanness. Lifestyle centers and the commodified city. In Setha Low (ed.), The Routledge handbook of anthropology and the city, 326-341. London: Routledge. 
Palmberger, Monika. 2018. Nationalizing the streetscape: the case of street renaming in Mostar, Bosnia and Herzegovina. In Reuben Rose-Redwood, Derek Alderman \& Maoz Azaryahu (eds.), The political life of urban streetscapes: Naming, politics, and place, 168-184. London: Routledge.

Pieters, Janene. 2018. Feminist group changes Dutch street names in protest for more female representation. https://nltimes.nl/ 2018/08/08/feminist-group- changes-dutch-street-names-protest-female-representation (accessed 19 January 2020).

Presseamt Stadt Münster. 2011. Informationen zum Thema “Strassennamen”. https://www.muenster.de/stadt/strassennamen/ pdf/strassennamen2011-06.pdf (accessed 27 April 2020).

Robinson, Adia. 2018. Here's what happened to the 'Kashoggi Way’ sign. https://www.washingtonian.com/2018/12/05/ khashoggi-way-sign- what-happened-saudi-embassy/ (accessed 19 January 2020).

Rose-Redwood, Reuben. 2011. Rethinking the agenda of political toponymy. Acme 10(1). 34-41.

Rose-Redwood, Reuben, Derek Alderman \& Maoz Azaryahu. 2010. Geographies of toponymic inscription: New directions in critical place-name studies. Progress in Human Geography 34(4). 453-470.

Rose-Redwood, Reuben, Derek Alderman \& Maoz Azaryahu. 2018a. The urban streetscape as political cosmos. In Reuben Rose-Redwood, Derek Aldermann \& Maoz Azaryahu (eds.), The political life of urban streetscapes: Naming, politics, and place, 1-24. London: Routledge.

Rose-Redwood, Reuben, Derek Alderman \& Maoz Azaryahu. 2018b. Contemporary issues and future horizons of critical urban toponymy. In Reuben Rose-Redwood, Derek Alderman \& Maoz Azaryahu (eds.), The political life of urban streetscapes: Naming, politics, and place, 309-319. London: Routledge.

Sotoudehnia, Maral. 2018. Toponymic checksum or flotsam? Recalculating Dubai's grid with Makani, "the smartest map in the world”. In Reuben Rose-Redwood, Derek Alderman \& Maoz Azaryahu (eds.), The political life of urban streetscapes: Naming, politics, and place, 290-308. London: Routledge.

Sweeney, Joe. 2019. Paint can vandals are terrorising this town. https://www.birminghammail.co.uk/black-country/paint-canvandals-terrorising-town- 15775853 (accessed 19 January 2020).

Taz. 2017. Umbenennung von Straßen „Die ganze Stadt als Stolperstein“. https://taz.de/Umbenennung-von-Strassen/!5436192/ (accessed 19 January 2020).

Verdery, Katherine. 1991. National ideology under socialism: Identity and cultural politics in Ceauşescu's Romania. Berkeley: University of California Press.

Whelan, Yvonne. 2011. (Inter)national Naming: Heritage, Conflict and Diaspora. Acme 10(1). 7-12.

Wines, Michael. 20072. Where the road to renaming does not run smooth. https://www.nytimes.com/2007/05/25/world/africa/ 25durban.html (accessed 19 January 2020).

Yeoh, Brenda. 1992. Street names in colonial Singapore. Geographical Review 82(3). 313-322. 
DuEPublico

Duisburg-Essen Publications online

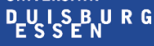

offen im Denken

Ub | $\begin{aligned} & \text { universitäts } \\ & \text { bibliothek }\end{aligned}$

This text is made available via DuEPublico, the institutional repository of the University of Duisburg-Essen. This version may eventually differ from another version distributed by a commercial publisher.

DOI: $\quad 10.1515 /$ lingvan-2020-0150

URN: urn:nbn:de:hbz:464-20220121-121201-2

Buchstaller, Isabelle. "Community cityscape: modes of engagement and co-construction of the streetscape" Linguistics Vanguard, vol. 7, no. s5, 2021, pp. 20200150. https://doi.org/10.1515/lingvan-2020-0150

This publication is with permission of the rights owner freely accessible due to an Alliance licence and a national licence (funded by the DFG, German Research Foundation) respectively.

All rights reserved. (C) 2021 De Gruyter Mouton 